\author{
B.Shayakhmetova ${ }^{1}$, N.Orumbayeva ${ }^{1}$, Sh.Omarova $^{2}$, Yu.Antipov $^{3}$ \\ ${ }^{1}$ Ye.A. Buketov Karaganda State University, Kazakhstan; \\ ${ }^{2}$ Karaganda Economic University of Kazpotrebsoyuz, Kazakhstan; \\ ${ }^{3}$ Kaliningrad Technical University, Russia \\ (E-mail: orumbayevan@mail.ru)
}

\title{
Analysis of theoretical and methodological bases of teaching object-oriented programming languages in higher school
}

\begin{abstract}
One of the most urgent tasks of our time is the problem of teaching in higher education. The task of teachers is to train young people in the field of the latest computer technologies. When teaching, the teacher must also change the methodology of training specialists in higher education in an adequately changing pace of development. Recently, there has been a definite bias towards the creation of software for complex systems, the tasks under consideration are becoming much more complicated, so there are not enough old techniques and methods used earlier to create simple or formalized programs. And in this regard, we will consider in detail the paradigm of object-oriented technology, which is developing at the present time.
\end{abstract}

Keywords: analysis, development, complex systems, information, object-oriented approach, model, education, methods, pedagogics, algorithmization.

Software changes due to the appearance on the market of new information technologies. The subject area of computer science changes in an extremely dynamic way.

Teachers of higher school that teach subjects associated with the technology of software creation are constantly faced with the problems of changing the content of curricula, working programs, methodical support (lectures, labs, tests, etc.), the development of new teaching and learning aids.

In connection with the application in the educational process of the various versions of educational software, teaching guides on the use of this software have to be accordingly changed.

A certain bias towards the creation of software for complex systems has been recently observed; the tasks under consideration become much more complicated, so the old techniques and methods previously used to create simple or formalized programs are not enough.

Teachers themselves have difficulties to acquire literature and e-learning programs. Lack of financial opportunities for the acquisition of high-quality scientific literature is a factor that the level of training teachers in higher educational institutions lags behind the fast-changing pace of development of new information technologies.

Rapidly changing software and PC models require accordingly the change in the content of working programs on the courses «Programming technology» and «Algorithmization and programming languages». Students' training for professional activities is based on a set of necessary information subjects. Such a set should contain a sufficient number of theoretical and, especially, practical lessons.

Information profile subjects mentioned above are conducted in accordance with SES RK 23.08.1080-2012 curricula [1].

The Bachelor's qualification characteristics (specialty 5B070300 - «Information Systems», 5B070500 «Mathematical and computer modeling») in the Kazakhstani universities standards reveal the content of professional activities, which envisage the creation of information systems components, the production of software and software systems. Requirements to the key competences of the Bachelor on the specialty 5B070300 - «Information Systems» point out that Bachelor should be able to program with the use of modern instrumental tools to solve the professional tasks in a competent and responsible way. Thus, these educational standards reflect the requirements of the modern information society to those skilled in the activity. Requirements to the key competences of future specialists in computer science and information technologies declare the ability to create software products for complex systems.

Analyzing the list of information subjects taught in the universities of Kazakhstan, we can get an idea of what level of program complexity graduates will be able to develop on the basis of acquired knowledge, proceeding from the content of the proposed subjects and their volume. 
Kazakhstani universities' working plans have been considered and that showed a great variation in the number and volume of information subjects.

As it follows from the analysis performed, many universities, with few exceptions, teach students of information specialties to create programs for the formalized tasks or simple programs.

At the modern stage of social development, the needs of educational, industrial, commercial entities have significantly increased, and simple programs no longer meet them. However, training of students of information specialties today lags behind growing requirements. Education of students of information specialties has not been provided yet with the necessary theoretical basis for the creation of complex software systems, the necessary subjects are often presented in the curricula fragmentary, in the list of elective courses. They include systems analysis, programming in real-time regime, systems theory, WEB-programming, multimedia programming, object-oriented programming, CASE-technology and UML language, etc.

In order to justify the use of the methodology of teaching the technology of the creation of software for complex systems in the educational process of information specialties it is necessary to consider its structure and content in details.

Complex systems in their development (life cycle) go through the following stages: planning and risk assessment; system analysis and requirements analysis; designing algorithms, data structures and program structures; encoding; testing; support. The use of pedagogical complex «Creation of software products for complex systems based on the use of object-oriented technologies» developed by the authors [2] is expedient in the methodology of teaching the technology of the creation of software for complex systems. The role of the pedagogical complex is that it contains special courses, workshops, tutorials, etc. that describe each of the above mentioned stages, the sequence of their execution. Synthesizing, we obtain the software product for the initial system.

As stated above, one of the ways to solve the problem of teaching programming at the level of the creation of programs for complex systems is the use of the proposed pedagogical complex «Creation of software products for complex systems based on the use of object-oriented technologies» in the educational process of information specialties. The need for the introduction of this complex into the educational process is supported by the results of the Kazakhstani universities curricula analysis, as the disciplines associated with the creation of software products for complex systems are currently not comprehensively taught, which adversely affects the preparation of information specialties students for their professional activities.

Obvious advantages of software creation technologies are the natural character of their methodology, the use of similar terms application areas, the ability to use a friendly user's interface. In addition, the software creation technology assumes the unity and a small number of basic designs, openness, extensibility, reusability of modules and their universality.

Software creation technologies would be best used in the development of bulk software products. The intensification of information processes predetermines the need to improve education. It is possible to consider various aspects of the problem; there are philosophical, social, psychological and pedagogical issues of the modern information society's functioning.

They determine the following ways to improve the system of education:

- an active use of information systems in the management of education;

- formation in the trainees of the desire for self-learning as an essential factor of the individual to adapt to the changing conditions of the professional activity;

- the use of the modern means of communication to find information and get an access to it.

The current state of educational research related to the programming teaching process is characterized by the search and application of formal methods, system-cybernetic approach to constructing methodical training systems. But the development of educational technology of programming teaching, which allows achieving the teaching objectives under the conditions of the object development of information processes, is far from being completed.

Many believe that the solution of the modern pedagogical problems requires a significant upgrade of teachers' relation to the definition and development of educational objectives, selection, structuring of their content, searching for new teaching methods and technologies. We pay our attention to the necessity of timely teachers' retraining with the use of innovative technologies for the development of new methods of work with students.

The study of innovative pedagogical technologies can be considered as the basic methodological approach based on complementarity of methods of science and human cognition.

The following ones can be considered to be the leading features of pedagogical training technology: diagnostically specified objectives, reproducibility, determinism of teaching process, its division into stages, stages algori- 
thmization, determination of stages consequence, teaching process control, presentation of the studied content in the form of the system of cognitive and practical tasks, orienting basis and ways of their solution.

We should also pay attention on the fact that nowadays it's necessary to conduct various researches on such issues as the description and measurability of educational objectives, means, results, availability of the educational content to the technological form of its presentation (training courses are often incorrect, illogically designed, which doesn't allow them to be technologized).

Extensive use of cybernetics, synergetics, information science in the development of innovative pedagogical technologies is defined not only in teachers' scientific researches but also in the regulatory educational documents of many countries. For example, even the report «Education policy and new information technologies» at the II International UNESCO Congress in 1996 emphasized the special importance of information technologies as components of computer science, taking into consideration their wide application in various subject areas.

It also says that the distinguishing feature of the modern concept of teaching computer science in educational institutions is the use of the latest achievements of information technologies for the systemic, modular formation of training, based on the activity approach that allows, on the basis of the state educational standards, creating a program oriented on the future professional activity of students, taking into account their personal interests and abilities [3].

The analysis of theoretical research and practical experience on the path of improving teaching with the help of information technology tools have led to the conclusion about the necessity of searching for a new apparatus which can provide an overview of this subject area, in accordance with modern principles of didactics and an appropriate subject area in conditions of information processes intensification.

The way of thinking and its typical programming techniques make the programming paradigm. There is a direct link between the high-level programming languages and the existing programming paradigms.

The main part of the modern subject of information science, taught in most universities, represents questions connected with the programming teaching, the development of algorithmic thinking in students, and their preparation for the future professional activities using the latest instrumental systems and tools.

However, the increased requirements for this activity determine the need to improve the content and methodology systems of teaching programming. The ever-increasing necessity for professionals, who are able to handle procedural, object-oriented, logical and functional approaches to the development of algorithms and programs, makes students necessarily manage all the programming paradigms [4].

Analysis of modern methods and organizational forms of teaching programming in the university computer science courses determines the need to establish a system of courses based on the integration of programming paradigms, which is designed in accordance with the concept of computer science as a scientific discipline. Defining the essence of computer science subject and that of programming concept, it should be noted that programming is an essential part of computer science. Programming accumulates engineering issues of the algorithm implementation under the given spatio-temporal restrictions, taking into account the entire life cycle of a software product. Modern computer science course is the basis for the use of computers and software in the future professional activity of students.

Learning of several languages and programming paradigms enables us to use information technologies in the educational process on a new level of quality, makes it possible to form the necessary professional qualities of a future specialist.

The content of the training courses on computer science depends on the development of modern information and telecommunication technologies and on this basis is constantly being improved. Today, there is the need to develop a specialized system for training students, whose future profession is related to the area of computer science and the use of information technologies.

These are university students, whose future professional activity field is the development and operation of software, and students, who are studying for a degree in computer science. In the light of the development of these students' training due attention should be paid to the study of theoretical fundamentals and specific algorithmization and programming techniques [5].

A modern course in programming, based on the study of all the approaches to the development of algorithms, should give the necessary knowledge about the different linguistic means and other programming tools that allow building information technologies at this stage of computer science development.

Analysis of the development of programming ideas and their teaching shows that the main factor in their improvement has been the problem of creating software products for complex systems. 
In this connection, let us consider in more details the object-oriented technology paradigm, which currently develops.

An integral part of this stage is a visual programming technology. Some examples of programming languages used at this stage are Turbo Pascal version 5.5, Smalltalk, C ++, etc. The development of programming at this stage is carried out in two related directions:

- the development of the object-oriented approach;

- the development of the environment for the production of software tools offering higher level principles of decomposition, abstraction, and hierarchy.

It should be noted that after the development of structural programming standards an opportunity to put software production process on an industrial scale has appeared. However, today due to the increasing complexity of software and the requirement to reduce the time of its development, there appeared a need to create new programming technologies. The result of studying methodological approaches to the problem of software design is the development of methods of decomposition, abstraction, and the construction of a hierarchy. On this basis, the object-oriented methodology has been created.

Processing of a variety of information is carried out today with the help of computer technologies, which are improving very quickly. In the study of any models with the help of a computer user is studying changes in the state of objects and their interactions, which requires a solid representation of an object, and the software that defines the relationships between objects that are closely associated with it. The object-oriented approach to the development of software meets best the solution of this problem.

The modern stage of information science development is accompanied by the increase in requirements for software quality, which leads to the formation of a new programming paradigm. In this regard, scientificmethodological designs of the pedagogical information science deal with the issues of correspondence between the content of teaching information science, in particular, programming and the current state of computer science, which can be realized on the basis of the object-oriented approach.

At present the tendency of transition of software development to the object-oriented basis can be noticed. Object-oriented programming is the main paradigm of the creation and development of the modern software for complex systems.

In the theoretical and applied programming the object-oriented approach develops the most intensively. Its systemic application gives an opportunity to create structured, reliable and easily modified software systems. These circumstances explain the interest in the object-oriented approach and the object-oriented programming languages.

Nowadays almost every programming system is characterized by the object-oriented features. Thus, highlevel programming languages that do not have means to work with classes and objects, acquire language extensions that allow realizing the benefits of the object-oriented methodology. For example, the object-oriented language creation in $\mathrm{C}++$ can be considered as the necessary extension of $\mathrm{C}$ structural programming language. Object-oriented interface is becoming more common in the modern software systems today. These methods are being used in local as well as in global network systems.

Object-oriented development is a brand new mode of thought in programming, which is based on abstractions that exist in the real world. It is a process of logical design, which gives an opportunity to express abstract notions in a clearer way, it also makes an interaction between the customers and software products developers easier. Object-oriented development serves as a medium for the specification, analysis, documentation and interface, as well as for programming.

System requirements analysis for the object-oriented approach comes down to the development of this system models. The applied-oriented program system design starts with the analysis of requirements, which the system should meet. It is caused by the need to identify the purpose and conditions of system operation to make up its preliminary draft. Modeling is a widely used method of studying complex objects and events. Models give an opportunity to explore system working capabilities at the early stages of its development, help to clarify system requirements, and if necessary, allow correcting system design at any stage or phase of its life cycle.

In the object model, it is necessary to reflect notions and objects of the real world, which are important for the system being developed; the model describes the structure of the objects that make up the developing system, their attributes, operations and relations with other objects. Description of the set of objects and actions performed on them defines the class concept. In accordance with the terminology of the object-oriented programming language an object class is characterized as the defined base data type, and a separate object - as 
a variable of this type. The definition of object classes for a specific set of tasks allows the individual to describe the problem in terms of the class of problems.

The object-oriented approach requires the following during the program development: the attribution of the object used; the declaration of these objects; the creation of the necessary objects instantiations; the declaration of their interconnections.

Object-oriented approach requires to identify classes of objects used in the program, to build their description, and then to create samples of the necessary objects and to define interaction between them during the program design.

In the process of object-oriented subject area analysis abstractions and their general properties, the presence of which greatly simplifies the development of the applied task, are revealed. Object-oriented analysis has three stages:

- building information model, abstracting real entities in terms of objects and attributes;

- constructing the state model to formalize life cycles of objects and display of this model through diagrams and transition tables, where the interaction between objects involve sending messages about current events happened to them;

- development of process models, in which the actions of states models are subdivided into fundamental and reusable processes.

There are other approaches to the object-oriented analysis:

- formal description method, where nouns and verbs in the subject area description are revealed. Nouns are considered as candidates to form classes, and verbs - as candidates to operate with these classes.

- structural analysis, wherein due to the system model, represented by the data flowcharts, external events and objects, data basis, control flow and control flow transformation are noticed. Further, on the basis of the data flow analysis and the control flow analysis, classes and class methods are revealed.

- designing, as we can see, implies taking into account the set of conflicting requirements. Its products are models and algorithms that allow understanding the structure and functioning of the future system, balancing requirements and outlining the scheme of its application. Each model describes a certain part of the considered system in a certain aspect. Designing is to develop models of the future system.

Object-oriented designing is a progressive iterative process. The boundary between the object-oriented analysis and designing is conventional, the construction of the software product consists of a series of cycles, in which the descriptions of classes and the interactions between them are specified, programs that implement them are developed, their debugging and testing are conducted and according to the results of each stage working documents of the previous stages are clarified, descriptions of classes and programs are being finalized. These cycles are repeated until the desired result.

In the object-oriented approach to the software development one should base on the following assumptions:

- program is a model of a real process, that is of a part of the real world;

- a model of the real world (or part thereof) can be described as a collection of interacting objects;

- an object should be described with a set of parameters, the values of which determine its condition, and a set of operations that it can perform;

- interaction between objects is carried out by sending messages from one object to another; a message received by the object requires certain actions, for example, changes in the state of the object;

- class of similar objects is made up by objects described by the same set of parameters and capable of performing the same set of actions.

Computer software used in the production, business, research and other areas are developed on the basis of the real-world models. Models of real processes and systems are characterized by a set of variables called variable states. Changing the state of the process or system corresponds to a change of model's state variables. Mathematical model is generally described by a set of state variables and the relationship between these variables. State variables can be numeric or non-numeric, including words and sentences of a natural language.

Development and designing of complex systems programs is a time-consuming process. As an approach, organizing the structuring of the mathematical model and the simplifying of its programming, there is the object approach, which reflects the real system as a collection of interacting objects. The information model is designed by the principles of the object-oriented approach to research, design and implementation of the realworld models in computer environment. Object-oriented programming includes the best features of structural programming, complements it with new ideas, which transfer it into a new quality approach to creating programs that is ranked as the most modern approach to the creation of programs for complex systems. This technology is justified not only in terms of the process of drawing up the algorithms, but also in terms of the results of 
current research in the field of psychology, where the separation of subject area into objects and identification of their interactions most accurately correspond to the process of human mental activity.

Regulations on functional-system and object organization of mental processes are justified in psychological and educational research. Based on the research results of mathematical modeling, psychological and pedagogical aspects of the computerization of education and conclusions about the object-structural nature of human mental activity, and taking into account the degree of preparedness and practical opportunities for students, as well as the real need for the technological process of development of new information technologies, the need for teaching object-oriented programming at universities that prepare specialists in computer science should be noted. Application of object-oriented programming allows us to quickly develop complex software products. Therefore, the study of subjects' cycle on the object-oriented programming allows graduates of information specialties change the direction of their work from the applied to the systemic, depending on the industrial necessity.

\section{References}

1 Государственный общеобязательный стандарт образования Республики Казахстан. Образование высшее профессиональное. Бакалавриат. ГОСО РК 23.08.1080-2012. - Астана: Министерство образования и науки PK, 2012.

2 Шаяхметова Б.К. Технология создания программ для сложных систем / Б.К.Шаяхметова. - Астана: МПА Туран-Профи, 2010. - 170 с.

3 Национальный доклад РФ на II-м Международном конгрессе ЮНЕСКО «Образование и информатика», «Политика в области образования и новые информационные технологии». - М., 1996. $34 \mathrm{c}$.

4 Жужжалов В.Е. Интеграционные методы изучения программирования в вузовском курсе информатики / В.Е.Жужжалов // Вестн. МГПУ. Серия информатика и информатизация образования. M., 2003. - № 1 .

5 Вирт Н. Алгоритмы + структуры программ = программы / Н.Вирт. - М.: Мир, 1985. - 406 с.

\section{Б.Шаяхметова, Н.Орумбаева, Ш.Омарова, Ю.Антипов}

\section{Жоғары мектепте объектілі-бағытталған бағдарламалау тілдерінің теориялы-әдістемелік негіздерін оқытуды талдау}

Біздің заманымыздың ең өзекті міндеттерінің бірі жоғары білім беруде оқыту мәселесі болып табылады. Мұғалімдердің міндеті - жастарды жаңа компьютерлік технологиялар саласында оқыту. Оқытқан кезде мұғалім жоғары білім беру саласындағы мамандарды даярлаудың әдіснамасын өзгертуге тиіс. Қазіргі уақытта күрделі жүйелер үшін бағдарламалық жасақтаманы құруға қатысты белгілі бір көзқарас бар, қаралып отырған тапсырмалар әлдеқайда күрделі болып келеді, сондықтан қарапайым немесе формалданған бағдарламаларды жасау үшін бұрын қолданылған ескі әдістер мен әдістер жетіспейді. Осыған байланысты, бүгінгі күні дамып келе жатқан объективті-бағытталған технологиялардың парадигмасын егжей-тегжейлі қарастырамыз.

Kiлm сөздер: талдау, әзірлеу, күрделі жүйелер, ақпарат, объектілі-бағытталған көзқарас, модель, білім беру, әдістер, педагогика, алгоритм. 
Б.Шаяхметова, Н.Орумбаева, Ш.Омарова, Ю.Антипов

\section{Анализ теоретико-методологических основ преподавания объектно-ориентированных языков программирования в высшей школе}

Одной из самых актуальных задач нашего времени является проблема преподавания в высшей школе. Задачей педагогов является подготовка молодых людей в области новейших компьютерных технологий. При преподавании педагог должен адекватно меняющимся темпам развития изменить также методику подготовки специалистов в высшей школе. В последнее время наблюдается определенный уклон в сторону создания программного обеспечения для сложных систем, рассматриваемые задачи значительно усложняются, поэтому недостаточно старых приемов и методов, применявшихся ранее для создания простых или формализуемых программ. И в этой связи подробно рассмотрим парадигму объектно-ориентированной технологии, которая развивается и в настоящее время.

Ключевые слова: анализ, разработка, сложные системы, информация, объектно-ориентированный подход, модель, образование, методы, педагогика, алгоритмизация.

\section{References}

1 Hosudarstvennyi obshcheobiazatelnyi standart obrazovaniia Respubliki Kazakhstan. Obrazovanie vysshee professionalnoe. Bakalavriat. HOSO RK 23.08.1080-2012 (2012). [The State Compulsory Standard of Education of the Republic of Kazakhstan. Higher professional education. Baccalaureate. SES RK 23.08.1080-2012]. Astana: Ministerstvo obrazovaniia i nauki RK [in Russian].

2 Shayakhmetova, B.K. (2010). Tekhnolohiia sozdaniia prohramm dlia slozhnykh sistem [Technology of creating programs for complex systems]. Astana: Turan-Pro [in Russian].

3 Natsionalnyi doklad RF na II-m Mezhdunarodnom konhresse IuNESKO «Obrazovanie i informatika», «Politika v oblasti obrazovaniia i novye informatsionnye tekhnolohii» (1996). [National Report of the Russian Federation at the II International UNESCO Congress «Education and Computer Science», «Education policy and new information technologies»]. Moscow [in Russian].

4 Zhuzhzhalov, V.Ye. (2003). Intehratsionnye metody izucheniia prohrammirovaniia v vuzovskom kurse informatiki [Integration methods of learning programming in the higher school course of computer science]. Vestnik MHPU. Seriia informatika i informatizatsiia obrazovaniia - Bulletin of Moscow State Pedagogical University. A series of computer science and informatization of education, 1. [in Russian].

5 Virt, N. (1985). Alhoritmy + struktury prohramm $=$ prohrammy [Algorithms + program structure $=$ program]. Moscow: Mir [in Russian]. 